\title{
Germs, Bodies, and Selves: Tuberculosis, Social Government, and the Promotion of Health- Conscious Behavior in the Early Twentieth Century
}

\author{
Enric Novella
}

The late nineteenth century witnessed a growing awareness of the importance of poverty, overcrowding, malnutrition, lack of hygiene, and occupational hazards in causing tuberculosis. ${ }^{1}$ From the "fashionable" disease of the Romantics, which has traditionally been considered a crucial landmark in the emergence of the modern understanding of the "sick individual," ${ }^{2}$ the (professional and middle-class) public came to view consumption as a threatening social plague, which was closely related, like alcoholism and venereal disease, to the process of industrialization and the bad habits and living conditions of the (urban) working class. ${ }^{3}$ Certainly, many authoritative observers had suggested the association of tuberculosis with poverty, physical overexertion, and inadequate diet long before this period, but it was in this age of large population movements, acute social conflicts, and widespread fears of decadence and degeneration that consumption came to be generally viewed as a dark spot in the landscape of industrialization and even as a troublesome "rite of passage to modernity." As French historian Pierre Guillaume has stressed, persons affected by tuberculosis were seen thereafter-especially after Robert Koch

1 Thomas Dormandy, The White Death: A History of Tuberculosis (London: Hambledon Press, 1999), 43.

2 Susan Sontag, Illness as Metaphor (New York: Farrar, Straus \& Giroux, 1978), 27-37; Claudine Herzlich and Janine Pierret, Illness and Self in Society (Baltimore, MD: Johns Hopkins University Press, 1987), 24-37. More recently, consumption has also been interpreted as the quintessential condition that paved the way for the modern notion of chronic illnesses. See Carsten Timmermann, "Chronic Illness and Disease History," in The Oxford Handbook of the History of Medicine, ed. Mark Jackson (Oxford: Oxford University Press, 2011), 393-410.

3 Michael Worboys, Spreading Germs: Diseases, Theories, and Medical Practice in Britain, 1865-19oo (Cambridge: Cambridge University Press, 2000), 195-96. See also Pierre Guillaume, Du désespoir au salut: les tuberculeux aux 19e et 2oe siècles (Paris: Aubier, 1986), 131-69; or, more extensively, David S. Barnes, The Making of a Social Disease: Tuberculosis in NineteenthCentury France (Berkeley: University of California Press, 1995).

4 Mark Harrison, Disease and the Modern World: 1500 to the Present Day (Cambridge: Polity Press, 2004), 128. 
had established the infectious nature of the disease-as dangerous agents of contamination, thus representing a serious challenge for policy makers and an overt threat to the "societal organism" as a whole. ${ }^{5}$ In any case, there is no doubt that the new "social" view of tuberculosis served as a general justification for a new set of attitudes and behaviors. Most important, it provided the legitimation for the discourses and practices of social hygiene whose authoritarian intervention strategies-embedded in what Michel Foucault once described as "social governmentality" 6 — violated the principles of liberalism and invaded the private sphere of the laboring classes with the goal of spreading new values, habits, and ways of life. ${ }^{7}$

In Luxembourg, where the manifold consequences of the country's rapid transformation from a traditional agrarian society into one of the most important sites of the European steel industry were clearly visible at least from the late nineteenth century, these views were widely shared by almost every active member of the national anti-tuberculosis movement. ${ }^{8}$ For instance, a report written by a special commission appointed by the government in 1920

5 Pierre Guillaume, "Histoire d'un mal, histoire globale: Du mythique à l'economique," in Peurs et terreurs face à la contagion: Choléra, tuberculose, syphilis (XIXe-XXe siècles), ed. Jean-Pierre Bardet, Patrice Bourdelais, Pierre Guillaume, François Lebrun, and Claude Quétel (Paris: Fayard, 1988), 159-83.

6 For a general assessment of the historical incarnations of governmentality, see Mitchell Dean, Governmentality: Power and Rule in Modern Society, 2nd ed. (London: Sage, 2010).

7 See Linda Bryder, Below the Magic Mountain: A Social History of Tuberculosis in TwentiethCentury Britain (Oxford: Clarendon Press, 1988), 142-48; Esteban Rodríguez Ocaña and Jorge Molero Mesa, "La cruzada por la salud: Las campañas sanitarias del primer tercio del siglo veinte en la construcción de la cultura de la salud," in La salud en el Estado del Bienestar: Análisis histórico, coord. Luis Montiel (Madrid: Editorial Complutense, 1993), 133-48; Alfons Labisch, "Sozialhygiene: Gesundheitswissenschaften und öffentliche Gesundheitssicherung in der zweiten Hälfte des 19. Jahrhunderts," in Sei sauber...!. Eine Geschichte der Hygiene und öffentlichen Gesundheitsvorsorge in Europa, ed. Musée d'Histoire de la Ville de Luxembourg (Cologne: Wienand Verlag, 2004), 258-67; Marjatta Hietala, "Zum Schularzt gehen, Milch trinken, Sport treiben: Hygiene als Volksaufklärung oder Sozialdisziplinierung," in Musée d'Histoire de la Ville de Luxembourg, Sei sauber...!', 286-301.

8 The most complete historical survey of the development of Luxembourg's steel industry is to be found in Charles Barthel and Josée Kirps, eds., Terres rouges: Histoire de la sidérurgie luxembourgeoise, 6 vols. (Luxembourg: Centre d'ètudes et de recherches européennes Robert Schuman/Archives nationales de Luxembourg, 2009-2018). Its huge significance to the national economy during the first half of the twentieth century is shown by the fact that Luxembourg became the country with the largest per capita steel production in the world, amounting to 5.48 tonnes per inhabitant in 1913 (compared to 0.26 in Germany, 0.17 in England, and 0.12 in France). Around 1950, the iron and steel industry contributed 31 percent to the national GDP. See Gérard Trausch, Les mutations economiques et sociales de la société luxembourgeoise depuis la révolution française (Luxembourg: Statec, 2012), 97, 153. 
stated that "to fight against this scourge is to fight against all damages caused by the transplantation of humanity and the individual from a world of clean air and healthy and balanced activity to an industrial environment with all its overwork and troubles." 9 The physician Ernest Feltgen, who was the first president of the Luxembourg Anti-Tuberculosis League (founded in 1908), used to provide the following standard explanation for the rise of the social disease of tuberculosis:

Agriculture is supplanted by industry, which grows at a prodigious pace. This situation results in the development of overcrowded cities, where there is a marked lack of space, air, and sun. It is clear that the victims of these unhealthy living conditions bring forth offspring prone to physical and moral degeneration, offering a fertile ground to host and germinate the virus of social diseases such as tuberculosis. ${ }^{10}$

Furthermore, it was frequently argued that the small country and its economic development had other singularities that created an even more fertile soil for the propagation of infectious diseases, such as its strategic geographical location at the crossroads between central and western Europe and the constant need for foreign workers-coming mainly from southern Italy and other poor regions - of the country's booming mining and metallurgical industry.11

In some countries, the national associations and private charities that, starting in France in 1891, carried out the fight against tuberculosis at the turn of the twentieth century were supported or even actively promoted by prominent industrialists. On the one hand, these captains of industry shared the ideology of individual responsibility underlying hygienic discourses; on the other hand, they were obviously concerned about a disease that was responsible for significantly decimating their workforce. ${ }^{12}$ Recent research has suggested that questions of labor and economy were indeed the main prisms through

9 Commission Spéciale de Lutte contre la Tuberculose, "La lutte contre la tuberculose par l'hygiène spéciale," 1921, Archives nationales de Luxembourg (henceforth ANLux), folder SP-271. Unless noted otherwise, all translation are the author's.

10 Ernest Feltgen, Nos principales œuvres pour l'enfance (Luxembourg: Société d'Hygiène Sociale et Scolaire, 1938), 6.

11 Aline Mayrisch, Rapport sur l'état actuel de la question de la tuberculose dans le GrandDuché et sur les meilleures méthodes à suivre pour la résoudre (Luxembourg: Société de la Croix-Rouge Luxembourgeoise, 1928), 9.

12 Marie-Paule Jungblut, "Öffentliche Gesundheitsvorsorge in Europa: Private Initiative und nationale Reglementierung," in Musée d'Histoire de la Ville de Luxembourg, Sei sauber...!, $278-85$. 
which tuberculosis came to be viewed as a problem for the government, and through which it was problematized as a public health issue. ${ }^{13}$ This would certainly explain the eagerness with which many industrialists contributed to the fight against the disease, but also the fact that these campaigns were broadly conceived as truly national endeavors prompting government intervention in order to maintain and safeguard the state's wealth and prosperity.

These considerations seem to be particularly pertinent in the case of Luxembourg's anti-tuberculosis movement, which evolved in a period of strong social and national challenges and soon secured a high degree of support from the country's main industrial companies. Focusing on the important role played by local industrialists and associated circles in the fight against consumption and on the main strategies and events of the ambitious health education campaigns launched in the interwar period, this chapter will show how industry-related entrepreneurship in the domain of tuberculosis prevention and treatment was essentially inspired by educational conceptions and, more particularly, by the goal of creating new patterns of subjectivity and citizenship for the country's working class.

\section{1 \\ The Political Economy of Consumption}

Although the real extent of the problem was never thoroughly assessed, there can be no doubt that tuberculosis was Luxembourg's most important public health challenge during the first decades of the twentieth century. And considering the fact that it was a disease that killed primarily young adults - that is, people in the prime of their working life - it is not surprising that, apart from its substantial demographic impact in such a small country, most physicians, as well as politicians and industrialists, were concerned especially about its huge economic effects.

As we have already seen, the emergence of this "white plague" was generally attributed to the process of industrialization and the living conditions of the working class, and many observers blamed particularly the bad habits of the growing number of foreign workers for spreading the disease on Luxembourg soil. ${ }^{14}$ This was, for example, the point of view of the Collège Médical, which

13 Alison Bashford, "Tuberculosis and Economy: Public Health and Labour in the Early Welfare State," Health \& History 4 (2002): 19-40.

14 As Michael Worboys has shown, the "metaphor of seed and soil" remained one key element in the medical understanding of tuberculosis even after the discovery of the infectious nature of the disease, as it allowed constitutional notions to be refashioned in terms 
in 1906 stressed the high rates of alcoholism among infected workers and described them in the following terms:

This poor patient corresponds to the type of the Italian miner, who is often predisposed to tuberculosis due to his physical inferiority. From a constitutional point of view, this type provides a breeding ground for the outbreak of infectious diseases, and most especially tuberculosis, whose germ he often brings from his country of origin. ${ }^{15}$

From the perspective of the workers' movement, things looked, of course, a bit different. Although it recognized that alcoholism was frequently present, it argued that the laboring classes were prone to get infected rather through their exposure to the unhealthy working and living conditions of the modern industrial world. As the social democratic newspaper Der arme Teufel (The poor devil) stated:

As time goes by, the notion according to which the massive spread of tuberculosis is caused by our social conditions is gaining more and more support; consumption cannot be effectively fought as long as poverty and malnutrition, airless houses and alcoholism reduce, as they did in the past, the bodily resilience of millions of workers. ${ }^{16}$

Consequently, it was argued that the fight against tuberculosis should not only include efforts to substantially improve this unhealthy environment; industrialists and the upper classes should significantly contribute to the treatment of those workers who had already been struck by the disease. ${ }^{17}$ Echoing these views, several authoritative voices from the country's health professions

of individual and collective vulnerability linked to certain habits and values. See Worboys, Spreading Germs, 193.

15 Collège Médical, Proposition de loi concernant la création d'un sanatorium dans le GrandDuché: Avis du Collège Médical (Luxembourg: Imprimerie de la Cour Victor Buck, 1906), 2. Interestingly, these arguments would appear again in the public discourses on tuberculosis prevention during the economic crisis of the 1930s. For instance, the medical director of the dispensary in the mining and metallurgical city of Esch-sur-Alzette stated in 1934 that, in order to protect the Luxembourgian people, all foreign workers with contagious forms of the disease should be banned from the country. See "Tuberkulose und Ausländer," Luxemburger Wort, March 5, 1934.

16 "Die soziale Bedeutung der Tuberkulose," Der arme Teufel, April 14, 1923.

17 In 1916, the leftist newspaper Escher Tageblatt appealed directly to the Grand Duchess and the country's millionaires to fund the national anti-tuberculosis campaign with their “surpluses." See “Tuberkulose und Krankenhaus," Escher Tageblatt, June 23, 1916. 
expressed the idea that the financial involvement in the anti-tuberculosis movement was the duty of "our powerful steel industry, for which a good part of our workers sacrifice their health and sometimes their lives." ${ }^{18}$ As nurse May Schoué pointed out, it was not only a matter of compensation or moral obligation, since "those who have the greatest interest in controlling this disease as a national epidemic are, first of all, our employers, who need to secure a skilled and efficient labor force and don't want to lose their best and most valuable people to tuberculosis."19 In fact, most of the country's main steel producers as well as some prominent industrialists took a very active role in this domain and became heavily involved in the funding and leadership of the national anti-tuberculosis movement.

Not long after the Luxembourg Chamber of Representatives had discussedwithout any significant outcome-a proposal to build a national sanatorium for consumptives, a small group of personalities headed by Ernest Feltgen, medical director of the reputed thermal facilities at Mondorf-les-Bains, and industrialist and Deputy Nicolas Ludovicy convened to create an association against tuberculosis. ${ }^{20}$ By the end of 1907 , this "provisional committee" issued a circulaire in French and German depicting the dramatic challenge posed by the disease and asking all Luxembourg citizens to join the crusade and become members of the "ligue antituberculeuse."21 Several months later, the new association held its first general meeting at Luxembourg City Hall, where it elected its first executive board under Feltgen's presidency, appointed a number of special delegates for each of the country's twelve cantons, and approved its statutes, which were validated in January 1911 by the Grand Duchy's government. According to this first public statement, the Ligue Luxembourgeoise contre la Tuberculose (Luxembourg Anti-Tuberculosis League) was constituted as a private entity with the goal of "fighting this scourge with therapeutic means and, most especially, with preventive measures," mainly through the establishment of a small network of dispensaries across the country, the organization of different resources for "children at risk," and ceaseless activity in the domains of propaganda and health education. ${ }^{22}$

\footnotetext{
18 Collège Médical, Proposition de loi, 8.

19 May Schoué, Eine volkstümliche, gemeinverständige Belehrung über die Tuberkulose als Volkskrankheit und deren Bekämpfung in Luxemburg (Bonn: Rhenania Druckerei, 1916), 38.

20 Anton Kayser, Proposition de loi tendant à la création d'un sanatorium populaire antituberculeux (Luxembourg: Imprimerie de la Cour Victor Buck, 1907).

21 "Ligue antituberculeuse. Liga gegen die Schwindsucht," SD, ANLux, folder SP-272.

22 Ligue Luxembourgeoise contre la Tuberculose, Assemblée Générale du 5 Avril 19o8. Statuts (Luxembourg: Imprimerie Joseph Beffort, 1908).
} 
The League quickly obtained official recognition as having legal personality - this enabled it to raise funds and receive tax-exempt donations and legacies ${ }^{23}$-and joined the International Association against Tuberculosis. Its members soon included a significant number of the country's physicians, politicians, civil servants, and industrialists, as well as the Royal Family. ${ }^{24}$ In fact, until the 1920s, when it became a more popular movement after a series of successful recruitment campaigns, it remained a charity whose members came mostly from the elites and the professional and upper-middle classes. By 1922, the association counted just 680 "paying affiliates," ${ }^{25}$ although these numbers rose to 3,000 in 1928 and to 5,400 in 1935 - that is, comprising more than 2 percent of the Grand Duchy's entire population. ${ }^{26}$

As has been already pointed out, from the very beginning many companies and leading figures of the local mining and steel industry were involved and gave personal and financial support to the activities of the League. Executive board members of several outstanding Luxembourg industrial businesses, such as Léon Kauffman, Norbert Metz and, particularly, Émile Mayrisch's wife Aline (née de Saint-Hubert), who in 1921 was appointed vice-president of the League, became key leaders of the movement. ${ }^{27}$ This involvement is best appreciated by looking at the sources of funding of the association, whose main

23 Chambre des Députés, Projet de loi avant pour objet de conférer la personnification civile à la Ligue Luxembourgeoise contre la Tuberculose (Luxembourg: Imprimerie de la Cour Victor Buck, 1910).

24 In 1911 and 1927, Grand-Duchess Marie-Anne and Grand-Duchess Charlotte respectively accepted the "high patronage" of the League. See Ligue Luxembourgeoise contre la Tuberculose, 1908-1933: 25 années de lutte antituberculeuse dans le Grand-Duché de Luxembourg (Luxembourg: St. Paul, 1934), 10.

25 Ligue Nationale Luxembourgeoise contre la Tuberculose, Son organisation, son fonctionnement, ses dispensaires, ses donateurs, sa situation financière (Paris: Braun \& Cie, 1922), 16.

26 Ligue Luxembourgeoise contre la Tuberculose, Rapport sur le fonctionnement de la Ligue en 1928, 1929, ANLux, folder SP-272; Ligue Luxembourgeoise contre la Tuberculose, Rapport du Conseil d'Administration à l'Assemblée Générale du 17 Mars 1935, 1935, ANLux, folder $\mathrm{SP}-272$.

27 As president of ARBED (Aciéries réunies de Burbach-Eich-Dudelange, a merger of the three largest Luxembourg steelworks brought about in 1911), Émile Mayrisch (1862-1928) was without question the most powerful, charismatic, and influential industrialist of his time and, together with his wife Aline (1874-1947), very active in social and cultural philanthropy. For instance, he introduced several social benefits for his workers, was for many years the president of Luxembourg's Red Cross, and used to gather a "circle" of artists, writers, intellectuals, and politicians at his country residence in Colpach. See, e.g., Nadine Schmitz, "Le paternalisme d'Émile Mayrisch," in Barthel and Kirps, Terres rouges, vol. 3, 104-53; Germaine Goetzinger, Colpach: ein Ort deutsch-französischer Begegnung zur Zeit der Weimarer Republik (Oldenburg: BIS der Universität Oldenburg, 2004); Klaus 
income was donations from the steel industry, at least until the early $1920 s$. Between 1908 and 1921, for example, these donations-coming mostly from ARBED, Gelsenkirchener Bergwerks-AG, Deutsch-Luxemburgische Bergwerks- und Hütten-AG (later renamed HADIR), and the Metz and Mayrisch families-amounted to over one million francs; in comparison, government subsidies only reached around 110,00o francs during the same period. ${ }^{28} \mathrm{Grad}-$ ually, these sums decreased and were surpassed by public funds and other means, such as the lucrative annual lottery that the League was authorized to sell from 1922 onwards. ${ }^{29}$ Nevertheless, industrial sources remained the most important single contributor to the treatment costs of tuberculosis through participation in the newly created Établissement d'Assurances Sociales (Social Insurance Institute) - which in the interwar period took an increasing role in this domain ${ }^{30}$ —and the development of its own care resources for tuberculous workers and their families.

Following the celebrated examples of Edinburgh (1887), Liège (1900), and especially Lille (1901), the League's most relevant institutional creations and the cornerstones of its activity were undoubtedly the dispensaries. ${ }^{31}$ According to the League's first annual report, the dispensaries had "an exclusively educational character refraining from every kind of therapy" and were responsible for the screening of infected persons and their families, the supervision of their housing conditions, the provision of material relief for poor consumptives, the delivery of spittoons, the performance of disinfections, and the referral of "appropriate" cases to sanatorium treatment. ${ }^{32}$ The first dispensary opened in Luxembourg City in August 1908, others followed in the country's main population centers, including Esch-sur-Alzette (1910), Ettelbruck (1910), Dudelange (1913), Differdange (1921), Grevenmacher (1921), Rédange (1921), Wiltz (1921), and Echternach (1936).

Dittrich, "Buddhism, Business, and Red-Cross Diplomacy: Aline Mayrisch de SaintHubert's Journeys to East Asia in the Interwar Period" (in this volume).

28 Ligue Nationale Luxembourgeoise contre la Tuberculose, Son organisation, 37-39.

29 Ligue Luxembourgeoise contre la Tuberculose, 1908-1933, 8-9. Other (less important) funds came from the annual membership fees, the sale of flowers, and the periodic celebration of social events, parties, and benefit concerts.

30 Denis Scuto, "La naissance de la protection sociale au Luxembourg," Bulletin luxembourgeoise des questions sociales 10 (2001): 39-59.

31 María José Báguena Cervellera, La tuberculosis y su historia (Barcelona: Fundación Uriach 1838/1992), 67-68. In regard to dispensaries, Luxembourg was very much influenced by French and British practices. On French dispensaries, see Guillaume, Du désespoir au salut, 205-215; on British experiences, Bryder, Below the Magic Mountain, 33-36, 72-75.

32 Ligue Nationale Luxembourgeoise contre la Tuberculose, Compte rendu de la Ligue Nationale Luxembourgeoise contre la Tuberculose, 1908-1909, 1909, ANLux, folder SP-272, 2-4. 
As Auguste Delahaye, medical director of the dispensary in Luxembourg City, explicitly stated, it was clear from the outset that these institutions did not target the upper classes but that their main goal was to launch a thorough educational offensive among the working class in order to control the spread of the disease:

Our dispensaries are institutions whose primary purpose is to protect from tuberculosis the poor and the working class. It is in these popular circles where we have to seek out workers and indigents affected by the disease; and it is through an active and continuous propaganda that we need to attract them to the dispensary and instil into their minds the absolutely essential notions of their illness and the hygienic measures they have to follow for their own interest and that of their environment. ${ }^{33}$

In fact, from 87 new cases of tuberculosis-out of 239 consultations-which were diagnosed in his dispensary in its first eight months of activity, Delahaye could confirm that around 20 percent were metallurgical workers, 21 percent had a familial history of the disease, and more than 33 percent were housed in inadequate conditions. ${ }^{34}$ Apart from bad housing, and according to conventional medical opinion, Delahaye pointed out the central role of overwork (surmenage) and insufficient nutrition in order to account for this high proportion of industrial workers. ${ }^{35}$ Other authors more specifically attributed the disease to mining and metallurgical work, which tended to facilitate contagion through the inhalation of dust and other respiratory-damaging substances. ${ }^{36}$ Not surprisingly, the country's steel industry gave support to the League's network of dispensaries, with ARBED and HADIR funding the dispensaries in Dudelange and Differdange respectively.

33 Ligue Nationale Luxembourgeoise contre la Tuberculose, Compte rendu, 2.

34 According to its annual reports, from 1908 to the outbreak of World War I, over 1,100 persons out of around 4,300 consultations were diagnosed with tuberculosis at the League's dispensaries. See Ligue Nationale Luxembourgeoise contre la Tuberculose, Rapport moral, médical et financier sur l'exercice 1914 présenté à l'assemblée générale des sociétaires du 28 mars 1915. Statuts (Luxembourg: Imprimerie de la Cour Victor Buck, 1915).

35 Ligue Nationale Luxembourgeoise contre la Tuberculose, Compte rendu, 3.

36 Schoué, Eine volkstümliche, gemeinverständige Belehrung, 28. In England, for instance, this association received special attention due to the high rates of pulmonary tuberculosis in industries with pneumoconiosis risk such as tin and copper mining, metal-grindery, and extraction and processing of slate. See Bryder, Below the Magic Mountain, 126. See also Francis B. Smith, The Retreat of Tuberculosis, 1850-1950 (London: Croom Helm, 1988), 212-16. 
In this context, it is worth quoting Aline Mayrisch, who personally organized and supervised the League's dispensaries from 1921 and who noted that "a society for the fight against tuberculosis without dispensaries would be like an army without intelligence and scout services." ${ }^{37}$ In order to improve this particular kind of service, one of her first initiatives was therefore to hire two visiting nurses, Elise Kauffeld and Anna Stirn, who had received special training in Paris and Brussels and were attached to the dispensaries in Luxembourg City and Dudelange. Within a short time, these nurses became key figures of the anti-tuberculosis movement and took charge of the majority of the dispensaries' daily activities, forming a veritable phalanx of surveillance and health education practices. Considering their experience and expertise, the League proposed to expand their tasks and duties in the 1920 s to the fight against poverty and all social diseases as "hygiene instructors for mothers and housewives, and for all sectors of the population which are not sufficiently trained in this regard." ${ }^{38}$ This led some years later to the emergence of related professions, such as so-called polyvalent nurses, social hygiene assistants, and social workers. ${ }^{39}$

The League also played an important role in the creation and maintenance of the small network of sanatoriums for consumptives established in Luxembourg in the first third of the twentieth century. As we have seen, the project of creating a national sanatorium for the treatment of tuberculosis had been presented to the Chamber of Representatives as early as 1906, and it was discussed again in $1918 .^{40}$ In this context, the League, in 1911, received a donation of 312,500 francs from Léopold Richard, one of the richest steel barons in the country, with the explicit stipulation that a sanatorium be built in the northern

37 Ligue Nationale Luxembourgeoise contre la Tuberculose, Son organisation, 23.

38 Ligue Nationale Luxembourgeoise contre la Tuberculose, Question des dispensaires, SD (1928), ANLux, folder SP-287, 2.

39 Marco Hoffmann has stated that "unlike other countries, where poverty was at the origin of professional social work, Luxembourg did not know this process. The causes and social impact of tuberculosis paved here the way for social professions." Marco Hoffmann, $L e$ développement du travail social au Luxembourg à travers l'activité centenaire de la Ligue Médico-Social (Luxembourg: Ligue Luxembourgeoise de Prévention et d'Action MédicoSociales, 2008), 8. See also Ligue Luxembourgeoise contre la Tuberculose, 1908-1933, 1820; Fernande Gretsch, "L'assistante d'hygiène sociale: Évolution d'une profession," in Ligue Luxembourgeoise contre la Tuberculose 1908-1968 (Luxembourg: Imprimerie de la Cour Joseph Beffort, 1968), 47-52.

40 "Proposition de loi betreffend Bau eines Sanatoriums zur Aufnahme an Tuberkulose erkrankter Frauen und Kinder," December 6, 1918, ANLux, folder CdD-2723. 
city of Wiltz. ${ }^{41}$ Shortly afterwards, the League's executive board acquired a plot of land and launched an architectural competition for the building, but the outbreak of World War I forced a delay to the project and, finally, construction work had to be stopped in 1920 because of rising post-war inflation and manpower costs. ${ }^{42}$

After the Social Insurance Institute had opened two provisional sanatoriums for male patients at the commune of Feulen and the forest of Baumbusch in 1915 and 1919 respectively, ${ }^{43}$ ARBED established a small "sanatorium annex for the rational treatment of tuberculous workers" at the factory hospital in Dudelange. ${ }^{44}$ Similarly, the League opened a sanatorium for around fifty women in a spacious property given by the city of Dudelange. This house, inaugurated in 1923 and staffed by Franciscan Sisters, was the only treatment site directly managed by the League, which also paid, if necessary, the cost of stays in Belgian, French, Swiss, and German institutions. Luxembourg's sanatorium movement was finally completed in 1931, when the Social Insurance Institute closed the premises in Feulen and Baumbusch and opened a sanatorium for 150 (male) patients in an idyllic mountain resort near the historic village of Vianden. ${ }^{45}$

According to contemporary beliefs about the virtues of institutional treatment, all these sanatoriums were designed to isolate patients in the early stages of the disease and-following the notion that had originated in Germany in the second half of the nineteenth century-provide them with the conventional regimen of rest, fresh air, and good food ${ }^{46}$ But in most cases, the main goal of sanatorium treatment was related to making patients regain their

41 Léopold Richard to Dr. Feltgen, September 13, 1910, ANLux, folder SP-271. See also Ligue Nationale Luxembourgeoise contre la Tuberculose, Rapport moral, médical et financier sur l'exercice 1911 présenté à l'assemblée générale des sociétaires du 31 mars 1912 (Luxembourg: Imprimerie P. Worré-Mertens, 1912), 11.

42 "Construction d'un sanatorium populaire à Wiltz: Programme du concours," May 21, 1913, ANLux, SP-268. See also Ligue Luxembourgeoise contre la Tuberculose, 1908-1933, 21. After the League was ordered to compensate the local architect who had originally won the contest for breach of contract, the project was abandoned for good and the premises in Wiltz were sold to the state in 1929.

43 See "Le sanatorium de l'établissement d'assurance contre la vieillesse et l'invalidité à Feulen," Luxemburger Illustrierte 45 (1925): 340; Henri Kugener, "Das Sanatorium im Baumbusch," Ons Stad 100 (2012): 66-70.

44 Ligue Nationale Luxembourgeoise contre la Tuberculose, Rapport sur l'exercice 1917, 1918, ANLux, folder SP-209.

45 Ligue Luxembourgeoise contre la Tuberculose, 1908-1933, 22-24.

46 On the foundations of the sanatorium movement in the United States and Europe, see Mark Caldwell, The Last Crusade: The War on Consumption, 1862-1954 (New York: Atheneum, 1988); Flurin Condrau, Lungenheilanstalt und Patientenschicksal: Sozialgeschichte der 
ability to work through a strict regimen of graded exercise and activity. ${ }^{47}$ This explains not only the fact that the majority of beds in Luxembourg's sanatoriums was reserved for male workers but also the significant involvement and support given to these institutions by the country's industries. The house rules at the League's sanatorium in Dudelange, for instance, stated explicitly that "a precondition for admission is that full recovery or a significant improvement can be expected after institutional treatment, so that long-term earning capacity can be restored." 48

To be sure, sanatoriums were not only clinical sites for the implementation of medical knowledge, but also pedagogical enterprises with vast educational objectives. ${ }^{49}$ As physician Anton Kayser declared in 1906, the creation of a popular sanatorium in Luxembourg was "a work of the utmost urgency and public utility, insofar as it would constitute "a school that will carry out a large part of the people's hygienic education." ${ }^{50}$ The crucial role of health education was repeated in almost every publication dealing with the nature of sanatorium treatment, which was supposed to act as a sort of "educational cure, [where] the doctor holds the whole life of the patient in his hands." ${ }^{51}$ According to Prosper Schumacher, medical director of the sanatorium in Vianden, the stay at the institution should enable patients to become "their own best doctors," so that they could keep themselves healthy (and productive) as long as possible after discharge. ${ }^{52}$

Following the broad international trend of refocusing efforts away from treating tuberculosis in adults to preventing the development of clinically active disease in so-called "pretubercular" or "tuberculosis-threatened" children, the League and related circles also put a strong emphasis on paediatric activities. ${ }^{53}$ In fact, in Luxembourg as elsewhere in the Western world, the fight

Tuberkulose in Deutschland und England während des späten 19. und frühen 20. Jahrhunderts (Göttingen: Vandenhoeck \& Ruprecht, 2000).

47 See Bryder, Below the Magic Mountain, 54-67, 157-73; Bashford, "Tuberculosis and Economy," $25^{-27}$.

48 Liga gegen die Tuberkulose, "Aufnahmebedingungen des Sanatoriums für weibliche Lungenkranke in Düdelingen," Der arme Teufel, February 10, 1923.

49 See Bryder, Below the Magic Mountain, 54-67; Rodríguez Ocaña and Molero Mesa, "La cruzada por la salud," 143-44.

$50 \quad$ Kayser, Proposition de loi, 3 .

$51 \quad$ Schoué, Eine volkstümliche, gemeinverständige Belehrung, 38.

$5^{2}$ Prosper Schumacher, Was muss jeder von der Tuberkulose wissen? (Luxembourg: Luxemburger Verlagsanstalt, 1927), 15 .

53 On these categories and related practices, see Cynthia Connolly, "Pale, Poor and 'Pretubercular' Children: A History of Pediatric Antituberculosis Efforts in France, Germany, and the United States, 1899-1929," Nursing Inquiry 11 (2004): 138-47; Teemu Ryymin, 
against tuberculosis played a key role in the development of many child welfare provisions, from school medical services to different initiatives set up to treat or protect children because of their poor health, sick parents, or hygiene and dietary deficiencies at home. ${ }^{54}$ Each of these interventions linked up the social and the medical, as this hygienic crusade was fed by a child-saving ethos that focused upon the poor and made working-class children the objects of surveillance, classification, and treatment. ${ }^{55} \mathrm{So}$, for instance, the Mayrisch family, between 1911 and 1913, sent a small group of children to a clinic in the German town of Bad Kreuznach, and between 1928 and 1938, the League, ARBED, and the city of Luxembourg booked a fixed amount of places for three-month stays at the preventoriums of Clemskerke and Breedene in Belgium. ${ }^{56}$

Together with the organization of holiday colonies in the spa resort of Mondorf-les-Bains and other locations across the country, these efforts crystallized in the introduction of three institutions that had originated in Germany, the United States, and France respectively. The first of these were the "forest" or "open-air" schools in Dudelange (1913) and Esch-sur-Alzette (1928), opened by ARBED in the wake of a report by a visiting commission on the pioneering centers of Charlottenburg, Elberfeld, and Mönchengladbach in Germany. These schools were designed to both promote health and re-educate "weak" or "sickly" children through a loose program combining regular lessons with respiratory exercises, sunbaths, (over)feeding, and rest, and were commonly attended by children from poor families associated with the local steel industry. ${ }^{57}$ The second set of institutions were the preventoriums opened in the early 1920 in the cities of Bettendorf and Remich by Franciscan Sisters and Sisters of Saint Elizabeth and, particularly, the so-called Maison des Enfants installed by ARBED at the old Mayrisch family home in Dudelange. Following the therapeutic regimen developed by Belgian physician Émile Spehl, this resort comprised a preventorium with fifty-six beds and a sanatorium with eighteen beds, and it provided a safe and strictly supervised environment where employees'

“'Tuberculosis-threatened Children': The Rise and Fall of a Medical Concept in Norway, c. 1900-1960," Medical History $5^{2}$ (2008): 347-64.

54 Nelleke Bakker, "Fresh Air and Good Food: Children and the Anti-Tuberculosis Campaign in the Netherlands, c. 1900-1940," History of Education 39 (2010): 343-61.

55 See here the essays included in Roger Cooter, ed., In the Name of the Child: Health and Welfare, 1880-1940 (London: Routledge, 1992).

56 Feltgen, Nos principales auvres pour l'enfance, 10. For its part, the local division of the Socialist Party in Esch-sur-Alzette every year sent a group of fifty selected children to a beach resort in the Belgian village of Lombartzyde.

57 Geert Thyssen, "The Open-Air Schools of Dudelange and Esch-sur-Alzette," Forum für Politik, Gesellschaft und Kultur 301 (2010): 40-42. 
children - especially those exposed to the possibility of contagion within their families - were instructed in the manifold benefits of a hygienic way of life. ${ }^{58}$ Finally, the last institutional practice consisted in placing "children at risk" with peasant families in the countryside, a practice popularized by the French CEuvre de Préservation de l'Enfance contre la Tuberculose (Childhood Preservation Work against Tuberculosis) founded by pediatrician Jacques-Joseph Grancher in $1903 .{ }^{59}$ In Luxembourg, this approach was introduced in 1928 by the Red Cross in the western commune of Redange, operating as a care center which distributed up to fifty small children "who should be separated from their families due to risk of tuberculosis infection." 60

As Cynthia Connolly has shown for other countries, each of these institutions - supported by industry, the League, the state, and other relevant actors - was a joint public-private venture and "did not just expose children to fresh air, provide good food and teach them hygiene; they also emphasised the importance of making children productive citizens of a nation-state." ${ }^{61}$ In this sense, and like many other initiatives in the health care sector, they were not only cheap alternatives to structural solutions for the workers' poor health and living conditions, but also an expression of the increasing modern tendency to "educationalize" social problems through institutions held accountable for solving them. ${ }^{62}$ "The patients," as the League's president Ernest Feltgen once put it, "are victims of abnormal social states and, in return, they undermine the foundations of society"; in his view, there was only one way of reversing this state of affairs resulting from "the conditions of modern life," namely by creating healthy citizens through ambitious educational initiatives focused on working-class children:

A big effort must be made to pull delicate plants out of the unhealthy environment where they pale lacking air and light, to transplant them into an oxygen-rich medium ... and to open new horizons to young minds which were hitherto confined to slum walls, narrow roads without

$5^{8}$ ARBED, CEuvres sociales (Luxembourg: Victor Buck, 1922), 23-37. On the origins of preventoriums, see Cynthia Connolly, Saving Sickly Children: The Tuberculosis Preventorium in American Life, 1909-1970 (New Brunswick, NJ: Rutgers University Press, 2008).

59 On Grancher, see Michèle Becquemin, Protection de l'enfance et placement familial: La Fondation Grancher. De l'hygiénisme à la suppléance parentale (Paris: Petra, 2005).

6o Croix-Rouge Luxembourgeoise, "Statuts du premier centre de placement familial," SD, ANLux, folder SP-003; see also Feltgen, Nos principales ouvres pour l'enfance, 11-12.

61 Connolly, "Pale, Poor and 'Pretubercular' Children," 144.

62 Marc Depaepe and Paul Smeyers, "Educationalization as an Ongoing Modernization Process," Educational Theory 58 (2008): 379-89. 
sunshine, and the black chimneys of the factories ... Social progress cannot be achieved without men in a state of complete bodily and mental health. ${ }^{63}$

Certainly, ARBED and other companies als undertook some "structural" initiatives, with the improvement in working conditions prescribed (among others) by the "Law concerning security and health in industrial and commercial companies" passed in $1903,{ }^{64}$ as well as the introduction of social benefits, such as pensions for widows and orphans, free attendance of vocational schools and kindergartens, food at reduced prices, and, more specifically, the construction of cités ouvrières (housing colonies). ${ }^{65}$ In doing so, industrialists met long-standing demands by social activists which were first voiced in 1907 in an influential report on the "housing conditions of poor workers in Luxembourg" drawn up by the Verein für die Interessen der Frau (Association for the Interests of Women), ${ }^{66}$ and their initiative was enthusiastically praised by prominent professionals involved in the anti-tuberculosis campaign. ${ }^{67} \mathrm{But}$ these programs only reached a small number of workers, and — as an internal ARBED document explicitly recognized - they were not intended as a result of a new "labor policy," but derived solely from "irrefutable community-oriented considerations!"68 For the most part, then, industry-related entrepreneurship in the domain of tuberculosis prevention and treatment aimed first and foremost at the rehabilitation of the labor force, and it was based, as we have seen,

63 Feltgen, Nos principales ouvres pour l'enfance, 6 -7.

64 See Jean J. Lentz, La lutte contre la tuberculose dans le Grand-Duché de Luxembourg (Luxembourg: Imprimerie de la Cour Joseph Beffort, 1934), 21-26.

65 See Antoinette Lorang, L'image sociale de I'ARBED à travers les collections du Fonds du Logement (Luxembourg: Le Fonds du Logement, 2009), 69-85. The important role of housing policies in the development of preventive medicine during the first third of the twentieth century has been emphasized by Dorothy Porter, Health, Civilization, and the State: A History of Public Health from Ancient to Modern Times (London: Routledge, 1999), 142.

66 According to this report, housing shortage was "the root of all material and moral evil," and it was easy to see that "every day this reform is postponed, it takes a particularly hard toll on women and children, that is, on the whole future generation of our workers and small artisans." Verein für die Interessen der Frau, Einiges über Wohnungsverhältnisse der ärmeren Arbeiterbevölkerung in Luxemburg (Luxembourg: Druck von M. Huss, 1907), 5 .

67 "Luxembourg's industry has masterfully cooperated in the realization of these principles by providing beautiful homes for their workers and employees. Nice apartment colonies where families can live healthily and happily have thus developed around our industrial centers." Schumacher, Was muss jeder von der Tuberkulose wissen?, 10.

68 "Die Sozialeinrichtungen der Vereinigte Hüttenwerke Burbach-Eich-Düdelingen AG ARBED in Luxemburg," 1942, ANLux, folder AES-U1-310. 
on pervasive health education practices through different strategies and institutions who targeted mainly the members and the offspring of the (urban) working class.

\section{Tuberculosis, Social Government, and the Self}

"Tuberculosis," Dr. Prosper Schumacher stated in 1927, "is a disease of ignorance." 69 Without question, this notion was from the outset one of the main axes of anti-tuberculosis action in Luxembourg, and even before the League's foundation, the fight against consumption generated a broad range of initiatives in the domain of health propaganda. As early as 1903, the country's government printed and distributed a German-language booklet which contained strict guidelines for the prevention and treatment of the diseaseincluding "safe disposal of sputum," "absolute cleanliness," "avoidance of debauchery," and, most especially, the "right combination of information and self-control," arguing that, insofar as "everybody [was] able to host the germ of the enemy, everybody [had] to be prepared for the fight against it."70

According to Ernest Feltgen, the improvement of national health should thus start with a thorough and continuous "hygienic education" of the masses, and these actions should, of course, focus on the key institution of the school: "It would be unfair to say that we have done nothing in terms of hygiene, but it is true that we need to do much more, especially in the field of the hygienic education of the people, which needs to start at school." ${ }^{71}$ Consequently, one of the main impetuses for the deployment of sustained and systematic efforts in health propaganda was the creation of the Verein für Volks- und Schulhygiene (Society for Social and School Hygiene) in 1904. Believing that "each human being represents a certain capital from a physical and moral point of view" and that "this capital has to be improved," ${ }^{72}$ a group of teachers, physicians,

69 Schumacher, Was muss jeder von der Tuberkulose wissen?, 7. Some years later, Schumacher outlined the "ten commandments of tuberculosis care"; see Prosper Schumacher, Wissenswertes über die Tuberkulose: Allgemeine Belehrungen (Vianden: Petingen, Meyer \& Hueber, 1939), 24.

70 Tuberkulose-Merkblatt bearbeitet im deutschen kaiserlichen Gesundheitsamte (Diekirch: Imprimerie J. Schroell, SD), 1-2. The content of this booklet was also reproduced in the leading newspaper Luxemburger Wort from September 29 to October 1, 1903.

71 Ernest Feltgen, Schulhygienische Mitteilungen vom Internationalen Tuberkulose-Kongress (Paris, 2-7. Oktober, 1905), (Luxembourg: n.p., 1905), 27.

72 Nicolas Wampach, "La Société Luxembourgeoise d'Hygiène Sociale et Scolaire depuis sa fondation jusqu'à nos jours," Revue d'hygiène sociale de Strasbourg 5 (1923): 73-77, quotation on 73. As Marjatta Hietala put it, "educational work in this domain was founded on 
and other professionals headed by Feltgen and school inspector Theodor Witry founded this association with the goal of "spreading the lessons of health care, especially in the country's schools." ${ }^{33}$ In the following decades, the society was very active in demanding the recruitment of school doctors, the installation of nurseries, or the construction of affordable houses, and it published a series of booklets and posters and organized several events—such as study tours, public lectures, conferences, courses, and film showings- devoted to the fight against tuberculosis and other "social maladies." In fact, the National League against Tuberculosis largely grew out of the Society for Social and School Hygiene, and both organizations shared members and cooperated closely in the realization of popularization activities. ${ }^{74}$

Beyond the placement of informative posters in railway stations and public buildings and the establishment in 1914 of a national day against tuberculosis on June $14,{ }^{75}$ these activities were intensified after 1920 as a result of the recommendations of the government commission mentioned above and, more particularly, of the visit to Luxembourg of the American Delegation for the Preservation of Tuberculosis in France funded by the Rockefeller Foundation. ${ }^{76}$ From May 10 to 17, 1920, a small group of this delegation - whose original goal was "to encourage the establishment of dispensaries, to develop centers for the

the belief that the most important resource of a nation was its people"; Hietala, "Zum Schularzt gehen," 292. On contemporary concerns regarding the quality and quantity of the population and their role in fostering public health campaigns, see Porter, Health, Civilization and the State, 174-177; and, more specifically, William H. Schneider, Quality and Quantity: The Quest for Biological Regeneration in Twentieth-Century France (Cambridge: Cambridge University Press, 2002); Virginia De Luca Barrusse, Population en danger! La lutte contre les fléaux sociaux sous la Troisième République (Bern: Peter Lang, 2013).

73 Verein für Volks-und Schulhygiene, Statuten des Vereins (Luxembourg: Druck von M. Huss, 1904), 3 .

74 Wampach, "La Société Luxembourgeoise d'Hygiène Sociale et Scolaire," 75. In this context, it is interesting to note that one of the first activities of the League was the installation, at the Luxembourg City Hall, of an exhibition on tuberculosis which had originally been assembled by the German physician August Dietz in Darmstadt. According to the first annual report of the League, the exhibition was a huge success and was visited by almost 10,000 people. Ligue Nationale Luxembourgeoise contre la Tuberculose, Compte rendu, 2.

75 Ligue Nationale Luxembourgeoise contre la Tuberculose, Son organisation, 11-13. This "national day" was introduced in most Western countries, although the dates varied. See Dominique Dessertine and Olivier Fauré, Combattre la tuberculose, 1900-1940 (Lyon: Presses Universitaires de Lyon, 1988), 128-38.

76 On the history of this delegation and its significant impact on the French campaign, see Lion Murard and Patrick Zilbermann, "La mission Rockefeller en France et la création du Comité national de défense contre la tuberculose (1917-1923)," Revue d'histoire moderne et contemporaine 34 (1987): 257-81. 
training of visiting nurses and physicians," and, most especially, "to conduct an energetic educational campaign on a national scale"77—visited the Grand Duchy at the League's request and offered a series of public lectures and film sessions for the general public. ${ }^{78}$ Thanks to this and other actions resulting from its international relations, ${ }^{79}$ the League acquired in 1922 its own "tuberculosis museum" and started organizing temporary exhibitions-often scheduled as part of so-called "tuberculosis weeks" - and similar activities across the country, sometimes alone and sometimes in collaboration with other private charities or public institutions. For instance, it provided broad support to the Volksgesundheitswoche (Public Health Week) celebrated in August 1926 in Luxembourg City, ${ }^{80}$ and it also actively promoted the big exhibitions of the German Hygiene Museum, "Der Mensch" (The Human Being) and "Das Leben" (Life), which were shown at the capital's city hall in 1928 and 1938 respectively. ${ }^{81}$

The pervasiveness of health education and propaganda is very illuminating in regard to the nature, reasons, and objectives of the thorough tuberculosiscentered sanitary offensive deployed in Luxembourg in the decades before World War II. On the one hand, the adoption of a new hygienic culture on the part of the population was seen - in the Grand Duchy as elsewhere-as the shortest way to achieve social peace and individual harmony and was often depicted as a veritable utopia. As sociologist Jean J. Lentz concluded in a detailed study of the anti-tuberculosis movement in Luxembourg, "The day man has learned to observe, to judge, and to constrain himself according to his needs, not only will the fight against the many scourges that afflict humanity have taken a big step forward, but the Golden Age awaiting men for ages will

77 The Rockefeller Foundation, Annual Report (New York, 1920), 97.

78 “Die Mission Rockefeller gegen die Tuberkulose in Luxemburg," Luxemburger Wort, May $11,1920$.

79 In this context, it is important to mention the visits to Luxembourg, in May 1925 and June 1926, of Lucien Viborel, propaganda director of the French Comité National de Défense contre la Tuberculose (National Defense Committee Against Tuberculosis). Other prominent foreign speakers invited by the League included the president of the International Union against Tuberculosis Léon Bernard (1921), Dr. Camille Guerin (1929), Professor Fernand Besançon (1930), and Dr. Karl Hansen (1931). See Ligue Luxembourgeoise contre la Tuberculose, 1908-1933, 12-13.

8o "Zur Volksgesundheitswoche," Luxemburger Wort, August 14, 1926.

81 It has been calculated that the first of these exhibitions was attended by over 25,000 visitors, almost 10 percent of the Grand Duchy's entire population. See Henri Kugener, “'In Spiritus gesetzte Naturseltenheiten, geburtshülfliche Präparate, Fötusse in allen Formen': $\mathrm{Zu}$ den Wanderausstellungen des Deutschen Hygiene-Museums in Luxemburg 1928 und 1938," in Musée d'Histoire de la Ville de Luxembourg, Sei sauber...!, 306-15. 
break forth on the horizon." 82 On the other hand, it is obvious that this hygienic culture was a project of the country's economic and professional elites, who imposed their health-related values, habits, and ways of life on the poor and working classes. Consequently, apart from preserving and improving the labor force, anti-tuberculosis action was-just like the fight against other social "scourges" of the period, such as alcoholism or venereal disease ${ }^{83}$ - a way of confronting the manifold social problems associated with the new conditions of modern industrial life (poverty, inequality, cultural uprooting, urbanization, etc.) through the (neutral) concept of health. And, as Alfons Labisch has pointed out, although "popular hygiene" and health education practices were based "on altering behavior through rational understanding, not on altering social conditions," this "offer of value-free 'health' as a scientifically-based mode of life" was ultimately very difficult to reject by the lower and subordinate classes. ${ }^{84}$

To sum up, anti-tuberculosis action in the Grand Duchy helped shape a comprehensive set of discourses and practices that encouraged the spread of health-conscious behavior and aimed at creating a "new worker" and a "new citizen" along the lines of the so-called "homo hygienicus" — that is, an individual who commits to keeping himself healthy for his own interest but also for his nation's sake. ${ }^{85}$ If hygiene and health education practices are thus essential

82 Lentz, La lutte contre la tuberculose, 130. As we have already seen, this emphasis on selfcontrol was common in almost every publication dealing with the fight against tuberculosis. In the words of nurse May Schoué, "on the threshold of the new era [of social hygiene], self-control is one of the main characteristics of the human being." May Schoué, An der Schwelle einer neuen Zeit (Luxembourg: St. Paulus Druckerei, 1920), 2.

83 On the close relationship between the three "crusades" (tuberculosis, venereal disease, and alcohol), see Christopher Lawrence, "Continuity in Crisis: Medicine, 1914-1945," in The Western Medical Tradition, 1800 to 200o, ed. W. F. Bynum, Anne Hardy, Stephen Jacyna, Christopher Lawrence, and E. M. Tansey (Cambridge: Cambridge University Press, 2006), 340-43. In Luxembourg, for instance, the three movements shared discourses, strategies, and protagonists, mainly though the transversal activity of the Society for Social and School Hygiene. See Wampach, "La Société Luxembourgeoise d'Hygiène Sociale et Scolaire."

84 Alfons Labisch, "Doctors, Workers and the Scientific Cosmology of the Industrial World: The Social Construction of 'Health' and the 'Homo Hygienicus," Journal of Contemporary History 20 (1985): 599-615, quotations on 605 and 608.

85 Labisch, "Doctors, Workers and the Scientific Cosmology of the Industrial World," 610-12. See also Porter, Health, Civilization and the State, 143: "It was no longer enough for individuals to heed their own health, as had been urged by the Enlightenment ideology of individual hygiene; they must be made conscious of the social impact of individual behaviour upon the health of the community." 
components of modern citizenship and nationhood, ${ }^{86}$ the history of tuberculosis, in Luxembourg as elsewhere, represents perhaps one of the best ways of understanding the making of this constitutive relationship.

\section{Sources and Bibliography}

\section{Archival Sources}

SP (Santé et Bienfaisance Publique), AE (Ministère des Affaires Étrangères), IP (Ministère de l'Instruction publique), J (Ministère de la Justice) $\mathrm{CdD}$ (Chambre des Députés), and ARBED Collections, Archives nationales de Luxembourg (ANLux).

\section{Primary Sources}

ARBED. CEuvres sociales. Luxembourg: Victor Bück, 1922.

Chambre des Députés. Projet de loi avant pour objet de conférer la personnification civile à la Ligue Luxembourgeoise contre la Tuberculose. Luxembourg: Imprimerie de la Cour Victor Buck, 1910.

Collège Médical. Proposition de loi concernant la création d'un sanatorium dans le Grand-Duché: Avis du Collège Médical. Luxembourg: Imprimerie de la Cour Victor Buck, 1906.

"Die Mission Rockefeller gegen die Tuberkulose in Luxemburg." Luxemburger Wort, May $11,1920$.

"Die soziale Bedeutung der Tuberkulose." Der arme Teufel, April 14, 1923.

Feltgen, Ernest. Nos principales œeuvres pour l'enfance. Luxembourg: Société d'Hygiène Sociale et Scolaire, 1938.

Feltgen, Ernest. Schulhygienische Mitteilungen vom Internationalen Tuberkulose-Kongress (Paris, 2-7. Oktober, 1905). Luxembourg: n.p., 1905.

Kayser, Anton. Proposition de loi tendant à la création d'un sanatorium populaire antituberculeux. Luxembourg: Imprimerie de la Cour Victor Buck, 1907.

"Le sanatorium de l'établissement d'assurance contre la vieillesse et l'invalidité à Feulen." Luxemburger Illustrierte 45 (1925): 340.

Liga gegen die Tuberkulose. "Aufnahmebedingungen des Sanatoriums für weibliche Lungenkranke in Düdelingen." Der arme Teufel, February 10, 1923.

Ligue Luxembourgeoise contre la Tuberculose. 1908-1933: 25 années de lutte antituberculeuse dans le Grand-Duché de Luxembourg. Luxembourg: St. Paul, 1934.

Ligue Luxembourgeoise contre la Tuberculose. Assemblée Générale du 5 Avril 19o8: Statuts. Luxembourg: Imprimerie Joseph Beffort, 1908.

Porter, Health, Civilization and the State, 7. 
Ligue Nationale Luxembourgeoise contre la Tuberculose. Rapport moral, médical et financier sur l'exercice 1911 présenté à l'assemblée générale des sociétaires du 31 mars 1912. Luxembourg: Imprimerie P. Worré-Mertens, 1912.

Ligue Nationale Luxembourgeoise contre la Tuberculose. Rapport moral, médical et financier sur l'exercice 1914 présenté à l'assemblée générale des sociétaires du 28 mars 1915. Statuts. Luxembourg: Imprimerie de la Cour Victor Buck, 1915.

Ligue Nationale Luxembourgeoise contre la Tuberculose. Son organisation, son fonctionnement, ses dispensaires, ses donateurs, sa situation financière. Paris: Braun \& Cie, 1922.

Mayrisch, Aline. Rapport sur l'état actuel de la question de la tuberculose dans le GrandDuché et sur les meilleures méthodes à suivre pour la résoudre. Luxembourg: Société de la Croix-Rouge Luxembourgeoise, 1928.

The Rockefeller Foundation. Annual Report. New York, 1920.

Schoué, May. An der Schwelle einer neuen Zeit. Luxembourg: St. Paulus Druckerei, 1920.

Schoué, May. Eine volkstümliche, gemeinverständige Belehrung über die Tuberkulose als Volkskrankheit und deren Bekämpfung in Luxemburg. Bonn: Rhenania Druckerei, 1916.

Schumacher, Prosper. Was muss jeder von der Tuberkulose wissen? Luxembourg: Luxemburger Verlagsanstalt, 1927.

Schumacher, Prosper. Wissenswertes über die Tuberkulose: Allgemeine Belehrungen. Vianden: Petingen, Meyer \& Hueber, 1939.

“Tuberkulose und Ausländer." Luxemburger Wort, March 5, 1934.

"Tuberkulose und Krankenhaus." Escher Tageblatt, June 23, 1916.

Tuberkulose-Merkblatt bearbeitet im deutschen kaiserlichen Gesundheitsamte. Diekirch: Imprimerie J. Schroell, SD.

Verein für die Interessen der Frau. Einiges über Wohnungsverhältnisse der ärmeren Arbeiterbevölkerung in Luxemburg. Luxembourg: Druck von M. Huss, 1907.

Verein für Volks-und Schulhygiene. Statuten des Vereins. Luxembourg: Druck von M. Huss, 1904 .

“Zur Volksgesundheitswoche." Luxemburger Wort, August 14, 1926.

\section{Bibliography}

Báguena Cervellera, María José. La tuberculosis y su historia. Barcelona: Fundación Uriach $1838,1992$.

Bakker, Nelleke. "Fresh Air and Good Food: Children and the Anti-Tuberculosis Campaign in the Netherlands, c. 1900-1940." History of Education 39 (2010): 343-61.

Barnes, David S. The Making of a Social Disease: Tuberculosis in Nineteenth-Century France. Berkeley: University of California Press, 1995.

Barthel, Charles, and Josée Kirps, eds. Terres rouges: Histoire de la sidérurgie luxembourgeoise. 6 vols. Luxembourg: Centre d'études et de recherches européennes Robert Schuman/Archives nationales de Luxembourg, 2009-2018. 
Bashford, Alison. "Tuberculosis and Economy: Public Health and Labour in the Early Welfare State." Health \& History 4 (2002): 19-40.

Becquemin, Michèle. Protection de l'enfance et placement familial: La Fondation Grancher. De l'hygiénisme à la suppléance parentale. Paris: Petra, 2005.

Bryder, Linda. Below the Magic Mountain: A Social History of Tuberculosis in TwentiethCentury Britain. Oxford: Clarendon Press, 1988.

Caldwell, Mark. The Last Crusade: The War on Consumption, 1862-1954. New York: Atheneum, 1988.

Condrau, Flurin. Lungenheilanstalt und Patientenschicksal: Sozialgeschichte der Tuberkulose in Deutschland und England während des späten 19. und frühen 20. Jahrhunderts. Göttingen: Vandenhoeck \& Ruprecht, 2000.

Connolly, Cynthia. "Pale, Poor and 'Pretubercular' Children: A History of Pediatric Antituberculosis Efforts in France, Germany, and the United States, 1899-1929." Nursing Inquiry 11 (2004): 138-47.

Connolly, Cynthia. Saving Sickly Children: The Tuberculosis Preventorium in American Life, 1909-1970. New Brunswick, NJ: Rutgers University Press, 2008.

Cooter, Roger, ed. In the Name of the Child: Health and Welfare, 1880-1940. London: Routledge, 1992.

De Luca Barrusse, Virginia. Population en danger! La lutte contre les fléaux sociaux sous la Troisième République. Bern: Peter Lang, 2013.

Dean, Mitchell. Governmentality: Power and Rule in Modern Society. 2nd ed. London: Sage, 2010.

Depaepe, Marc, and Paul Smeyers. "Educationalization as an Ongoing Modernization Process." Educational Theory 58 (2008): 379-89.

Dessertine, Dominique, and Olivier Fauré. Combattre la tuberculose, 1900-1940. Lyon: Presses Universitaires de Lyon, 1988.

Dittrich, Klaus. "Buddhism, Business, and Red-Cross Diplomacy: Aline Mayrisch de Saint-Hubert's Journeys to East Asia in the Interwar Period." In this volume.

Dormandy, Thomas. The White Death: A History of Tuberculosis. London: Hambledon Press, 1999 .

Goetzinger, Germaine. Colpach: ein Ort deutsch-französischer Begegnung zur Zeit der Weimarer Republik. Oldenburg: BIS der Universität Oldenburg, 2004.

Gretsch, Fernande. “L'assistante d'hygiène sociale: Évolution d'une profession." In Ligue Luxembourgeoise contre la Tuberculose 19o8-1968, 47-52. Luxembourg: Imprimerie de la Cour Joseph Beffort, 1968.

Guillaume, Pierre. Du désespoir au salut: les tuberculeux aux 1ge et 2oe siècles. Paris: Aubier, 1986.

Guillaume, Pierre. "Histoire d'un mal, histoire globale: Du mythique à l'economique." In Peurs et terreurs face à la contagion: Choléra, tuberculose, syphilis XIXe-XXe siècles, 
edited by Jean-Pierre Bardet, Patrice Bourdelais, Pierre Guillaume, François Lebrun, and Claude Quétel, 159-83. Paris: Fayard, 1988.

Harrison, Mark. Disease and the Modern World: 1500 to the Present Day. Cambridge: Polity Press, 2004.

Herzlich, Claudine, and Janine Pierret. Illness and Self in Society. Baltimore, MD: Johns Hopkins University Press, 1987.

Hietala, Marjatta. "Zum Schularzt gehen, Milch trinken, Sport treiben: Hygiene als Volksaufklärung oder Sozialdisziplinierung." In Musée d'Histoire de la Ville de Luxembourg, Sei sauber...!, 286-301.

Hoffmann, Marco. Le développement du travail social au Luxembourg à travers l'activité centenaire de la Ligue Médico-Social. Luxembourg: Ligue Luxembourgeoise de Prévention et d'Action Médico-Sociales, 2008.

Jungblut, Marie-Paule. "Öffentliche Gesundheitsvorsorge in Europa: Private Initiative und nationale Reglementierung." In Musée d'Histoire de la Ville de Luxembourg, Sei sauber...!, 278-85.

Kugener, Henri. “Das Sanatorium im Baumbusch.” Ons Stad 100 (2012): 66-70.

Kugener, Henri. "In Spiritus gesetzte Naturseltenheiten, geburtshülfliche Präparate, Fötusse in allen Formen': Zu den Wanderausstellungen des Deutschen HygieneMuseums in Luxemburg 1928 und 1938." In Musée d'Histoire de la Ville de Luxembourg, Sei sauber...!', 306-15.

Labisch, Alfons. "Doctors, Workers and the Scientific Cosmology of the Industrial World: The Social Construction of 'Health' and the 'Homo Hygienicus.' Journal of Contemporary History 20 (1985): 599-615.

Labisch, Alfons. "Sozialhygiene: Gesundheitswissenschaften und öffentliche Gesundheitssicherung in der zweiten Hälfte des 19. Jahrhunderts." In Musée d'Histoire de la Ville de Luxembourg, Sei sauber...!, 258-67.

Lawrence, Christopher. "Continuity in Crisis: Medicine, 1914-1945." In The Western Medical Tradition, 1800 to 200o, edited by W. F. Bynum, Anne Hardy, Stephen Jacyna, Christopher Lawrence, and E. M. Tansey, 340-43. Cambridge: Cambridge University Press, 2006.

Lentz, Jean J. La lutte contre la tuberculose dans le Grand-Duché de Luxembourg. Luxembourg: Imprimerie de la Cour Joseph Beffort, 1934.

Lorang, Antoinette. L'image sociale de I'ARBED à travers les collections du Fonds du Logement. Luxembourg: Le Fonds du Logement, 2009.

Murard, Lion, and Patrick Zilbermann. "La mission Rockefeller en France et la création du Comité national de défense contre la tuberculose (1917-1923)." Revue d'histoire moderne et contemporaine 34 (1987): 257-81.

Musée d'Histoire de laVille de Luxembourg, ed.Seisauber...!. Eine Geschichte der Hygiene und öffentlichen Gesundheitsvorsorge in Europa. Cologne: Wienand Verlag, 2004. 
Porter, Dorothy. Health, Civilization, and the State: A History of Public Health from Ancient to Modern Times. London: Routledge, 1999.

Rodriguez Ocaña, Esteban, and Jorge Molero Mesa. "La cruzada por la salud: Las campañas sanitarias del primer tercio del siglo veinte en la construcción de la cultura de la salud." In La salud en el Estado del Bienestar: Análisis histórico, coord. Luis Montiel, 133-48. Madrid: Editorial Complutense, 1993.

Ryymin, Teemu. “'Tuberculosis-Threatened Children': The Rise and Fall of a Medical Concept in Norway, c. 1900-1960." Medical History $5^{2}$ (2008): 347-64.

Schmitz, Nadine. "Le paternalisme d'Émile Mayrisch." In Barthel and Kirps, Terres rouges, vol. $3,104-53$.

Schneider, William H. Quality and Quantity: The Quest for Biological Regeneration in Twentieth-Century France. Cambridge: Cambridge University Press, 2002.

Scuto, Denis. "La naissance de la protection sociale au Luxembourg." Bulletin luxembourgeoise des questions sociales 10 (2001): 39-59.

Smith, Francis B. The Retreat of Tuberculosis, 1850-1950. London: Croom Helm, 1988.

Sontag, Susan. Illness as Metaphor. New York: Farrar, Straus \& Giroux, 1978.

Thyssen, Geert. "The Open-Air Schools of Dudelange and Esch-sur-Alzette." Forum für Politik, Gesellschaft und Kultur 301 (2010): 40-42.

Timmermann, Carsten. "Chronic Illness and Disease History." In The Oxford Handbook of the History of Medicine, edited by Mark Jackson, 393-410. Oxford: Oxford University Press, 2011.

Trausch, Gérard. Les mutations economiques et sociales de la société luxembourgeoise depuis la révolution française. Luxembourg: Statec, 2012.

Wampach, Nicolas. "La Société Luxembourgeoise d'Hygiène Sociale et Scolaire depuis sa fondation jusqu'à nos jours." Revue d'hygiène sociale de Strasbourg 5 (1923): 73-77. Worboys, Michael. Spreading Germs: Diseases, Theories, and Medical Practice in Britain, 1865-1900. Cambridge: Cambridge University Press, 2000. 